\title{
COP15’s forløb og historie
}

Bo Lidegaard

Perspektivet for et af de vigtigste topmøder nogensinde tegnede sig op til COP15 i København, men ikke perspektivet for en global aftale. Resultatet blev fortvivlende svagt i forhold til klimaudfordringen. Men det var samtidig det mest markante fremskridt i de internationale forhandlinger siden vedtagelsen af selve rammekonventionen

FN's klimatopmøde i København i december 2009 blev på mange måder sandhedens time for de internationale forhandlinger om klima og udvikling. De modsætninger, der havde præget arbejdet siden forhandlingerne om Klimakonventionen op til Rio-topmødet i 1992, brød ud i lys lue. Samtidig repræsenterede topmødet et politisk engagement uden fortilfælde, og det udviklede sig til en af de enestående lejligheder, hvor verdens ledere ansigt til ansigt drøfter globale spørgsmål af afgørende strategisk betydning for alle. Det var baggrunden for det kaotiske slutspil, som afspejlede en uventet åbning og deraf følgende usikkerhed hos afgørende aktører, om der var givet for store indrømmelser.

Resultatet, Copenhagen Accord, rummer ikke en konkret løsning på klimaudfordringen. Men det udgør det mest markante fremskridt i de internationale forhandlinger siden vedtagelsen af selve rammekonventionen. Det gælder så meget desto mere, som der i de bagvedliggende tekster ligger gennemforhandlede skitser til en mere substantiel aftale. Med Cancún Consensus i 2010 blev indholdet af Copenhagen Accord løftet ind i en vedtagen tekst, som nu indgår i de videre klimaforhandlinger. Men det måske vigtigste gennembrud i København, der afspejles i selve opbygningen af Copenhagen 
Accord, er stadig omdiskuteret. Ikke fordi forhandlingsresultatet var for svagt. Men fordi det er for stærkt.

\section{Baggrunden}

Under forhandlingerne op til vedtagelsen af FN's rammekonvention om klimaforandringer blev det klart, at spørgsmålet om begrænsning af menneskeskabte udledninger af drivhusgasser ikke kan adskilles fra udviklingsproblemerne. Når de to spørgsmål hænger så nøje sammen, skyldes det flere forhold.

For det første er der historisk en nøje sammenhæng mellem bedre levestandard og højere energiforbrug. Rige mennesker bruger væsentligt mere energi og udleder væsentligt flere drivhusgasser end fattige. Derfor anerkender alle, at en regulering må tage afsæt $\mathrm{i}$ en anden global fordeling af verdens goder i form af ressourceforbrug end den nuværende. Eller i det mindste må der tages højde for, at udviklingslandene nødvendigvis vil øge deres udledninger i takt med, at flere løftes ud af fattigdom og ind i en moderne markedsøkonomi.

Dette enkle forhold udgør en voldsomt komplicerende faktor i forhandlingerne. Dels er det meget vanskeligt at forhandle med afsæt $\mathrm{i}$ fremtidige udviklingsscenarier. Dels udgør hverken industri- eller udviklingslande homogene grupper. $\mathrm{Og}$ endelig er forholdet mellem udvikling og stigende udledning af driv- husgasser langt fra en entydig størrelse. Når en europæer kun bruger halvt så meget energi som en amerikaner, er det resultatet af en række politiske valg, herunder om regulering og afgifter.

For det andet hænger menneskeskabte klimaforandringer nøje sammen med en række fysiske forhold, der ikke har direkte at gøre med de enkelte landes udvikling. Mest kendt er betydningen af især de tropiske regnskove og deres funktion i de processer, der lagrer kuldioxid og omsætter det til ilt. Men der er en glidende overgang fra skovene til dyrket land, og det er ikke uden betydning, om jorden bruges til plantagedrift eller til anden landbrugsproduktion - eller til for eksempel produktion af biobrændsel.

Lande med store fysiske arealer spiller her en betydelig rolle, fordi de som forvaltere af skovområder og andre vidtstrakte naturområder har mulighed for at påvirke udviklingen direkte. Samtidig udgør skove og landbrugsarealer typisk en vigtig økonomisk og social faktor i de enkelte lande, som derfor er skeptiske over for internationale tiltag, der begrænser deres mulighed for selv at disponere over de pågældende ressourcer. En særlig, men bestemt ikke ubetydelig variant af denne problematik udgøres af produktion og eksport af fossile brændsler som kul, olie og gas. Lande, der økonomisk er afhængige af disse råstoffer, vil blive stærkt berørt af ethvert til- 
tag, der sigter mod at nedsætte forbruget af fossile brændstoffer. De deltager derfor i drøftelserne med mærkede kort.

Endelig har den globale opvarmning og den hyppigere forekomst af ekstreme vejrfænomener som tørke, orkaner og skybrud allerede stor betydning for menneskers liv og erhvervsudfoldelse overalt på jorden. Med noget der ligner en ond logik, følger virkningen af klimaændringerne det mønster, at de lande og områder, der har mindst historisk ansvar for udledningerne, og som er ringest rustet til at tilpasse sig de ændrede livsvilkår, rammes hårdere end den rigere del af verden, hvis infrastruktur også alt andet lige bedre kan modstå og tilpasse sig de nye forhold. Der er derfor blandt udviklingslandene et stærkt fokus på, at forhandlingerne om at imødegå menneskeskabte klimaændringer også må omfatte konkrete tiltag for at hjælpe de lande, der rammes hårdest. Klimatilpasning er en vigtig del af forhandlingerne, selv om de i sig selv ikke har væsentlig betydning for bekæmpelsen af klimaændringerne.

\section{Kompensation eller hjælp?}

I praksis er det imidlertid umuligt at sondre skarpt mellem generelle udviklingsproblemer og de problemer, der knytter sig til klimatilpasning. Ørkenudbredelse fandtes før klimaændringerne satte ind, men forværres af de lange tørkeperioder. De til- tag, det internationale samfund kan støtte for at imødegå denne tendens, er de samme, uanset hvordan man anskuer årsagerne til tørken. Men er støtten så at opfatte som en kompensation, som de rige lande, hvis historiske udledninger har forårsaget klimaændringerne, skylder de lande, det går ud over? Eller er den udtryk for udviklingshjælp til udsatte lande, hvis infrastruktur ikke kan håndtere de miljømæssige udfordringer?

Udviklingslandene mener principielt det første og insisterer derfor på, at støtten må gives uden de betingelser, der normalt knytter sig til udviklingssamarbejdet. Donorlandene har svært ved at sondre mellem det ene og det andet og mener i almindelighed, at betingelser er en forudsætning for at sikre, at hjælpen faktisk går til de formål, man er enige om, og får den tilsigtede virkning.

Ind i denne allerede dybt komplicerede diskussion kommer også spørgsmålet om støttens størrelse og dens forhold til udviklingsbistanden. Udviklingslandene frygter, at donorlandene i praksis blot har til hensigt at omallokere midler, der tidligere gik til udviklingsbistand, så de fremover øremærkes klimabistand. Dermed kommer i virkeligheden de typisk fattigere - udviklingslande, der ellers var tiltænkt bistanden, til at betale for øget klimastøtte til de typisk noget rigere - lande, der har særlig betydning for kampen mod 
global opvarmning. Den frygt er bestemt ikke uden grund. Men donorlandene hverken kan eller vil se de to typer bistand isoleret fra hinanden, og for de fleste er tanken om at give bistand uden tilknyttede betingelser, for eksempel om god regeringsførelse, hverken ønskelig eller politisk farbar. Donorlandene vil principielt gerne give tilsagn om, at klimabistanden skal lægges oven i den fattigdomsorienterede udviklingsbistand og dermed være 'additionel'. Men ingen kan forklare, hvad det betyder, når der ikke er en internationalt fastsat standard for hverken bistandens niveau eller for, om den forøges eller formindskes. I hvert fald ikke en standard, som efterleves af flertallet af industrilandene.

Hermed er allerede sagt, at klimaforhandlinger dækker et uhyre bredt politisk, samfundsøkonomisk og udviklingspolitisk felt, hvor landene indbyrdes har vidt forskellige interesser og synspunkter.

Som om det ikke var kompliceret nok, præges forhandlingerne samtidig af intens lobbyisme fra de mest forskellige samfundsaktører, spændende fra miljøorganisationer til nogle af verdens stærkeste erhvervsinteresser. Klimasagen havde op til klimakonferencen i 2009 et meget betydeligt politisk mobiliseringspotentiale, og talløse aktivister deltog $\mathrm{i}$ kampen for at nå det mest ambitiøse resultat. Kravet om at nå det højeste ambitionsniveau med en altomfat- tende og forpligtende aftale, der i selve sit sigte rummer en kontrakt om en mere retfærdig verdensorden, var imidlertid ikke nødvendigvis hjælpsomt i forhold til at opnå enighed om de langt mere begrænsede skridt, der var inden for rækkevidde blandt FN's næsten to hundrede medlemslande.

Der opstod i tiden op mod mødet i København et uheldsvangert skisma mellem denne verdens forhåbninger om det ideale på den ene side og de såre beskedne forpligtelser, de enkelte lande var villige til at påtage sig, på den anden.

Og det blev en del af mødets psykologi, at såvel de mest restriktive som de mere ambitiøse lande og lobbyister benyttede samme retorik om ønsket om en meget vidtgående og stærkt forpligtende aftale. Mens de første talte ambitionsniveauet op for at gøre målet uopnåeligt, talte folkelige bevægelser og de professionelle miljø- og udviklingslobbyister det op med ønsket om at nå de højeste mål. Problemet var, at mens alle talte forventningerne op, blev det i stigende grad klart, at de fleste mest havde ambitioner på andres vegne. Når det gjaldt de enkelte landes egne forpligtelser, var der til gengæld ikke grundlag for at finde et globalt kompromis.

\section{Den gordiske knude}

Det grundlæggende politiske problem blev formuleret allerede i for- 
bindelse med forhandlingerne om Klimakonventionen i 1992, og det er ikke blevet løst siden.

Konventionen taler om et fælles men differentieret ansvar for at løse klimaproblemerne. Den taler om, at de udviklede lande har en forpligtelse til at gå forrest men samtidig også om, at landene må bidrage i overensstemmelse med deres respektive kapaciteter. Det er alt sammen FNsprog for det fundamentale dilemma, at udviklingslandene har en berettiget forventning om, at industrilandene går i spidsen, når det gælder konkrete foranstaltninger til begrænsning af udledningerne. Industrilandene forventer omvendt, at især vækstøkonomierne bidrager på et niveau, der svarer til deres voksende betydning i verdensøkonomien og for udledningerne.

Kina overhalede i opløbet til København USA som verdens største udleder, og mens langt størstedelen af de historiske udledninger hidrører fra industrilandene, vil langt størstedelen af fremtidens komme fra vækstøkonomierne. I processen frem mod COP15 nærmede de fire store vækstøkonomier, Kina, Indien, Brasilien og Sydafrika, sig en forståelse om, at deres bidrag ganske rigtigt måtte være betydelige og større end de fattige udviklingslandes.

Men de stod fast på, at disse bidrag skete på rent nationalt grundlag og ikke som konsekvens af en forpligtende international aftale. Dette så meget desto mindre som det stod klart, at USA selv under den nyvalgte præsident Obama hverken kunne eller ville forpligte sig til konkrete reduktioner. Tilbage stod EU med ambitionen om en forpligtende aftale, der i videst muligt omfang fulgte mønsteret for Kyotoprotokollen, der blev vedtaget $\mathrm{i}$ 1997, og som trådte i kraft i 2005.

Selve formen for en aftale blev på den måde en alvorlig anstødssten i forhandlingerne, der afslørede, at verdens tre største økonomier og politiske systemer, EU, USA og Kina, har mere end vanskeligt ved at indgå aftaler, der i selve deres udformning ikke modsvarer deres egen strukturelle opbygning. Europa var i høj grad drivkraften bag Kyoto, som er bygget op som EU selv: en forpligtende juridisk aftale med konkrete målsætninger og et underliggende apparat til at overvåge deres gennemførelse. Denne model er juridisk og konceptuelt uspiselig for USA, som kategorisk afviser at underkaste sig et sådant internationalt regime. Kina har det grundlæggende som USA, men da Kyoto ikke pålægger Kina reduktioner eller andre konkrete forpligtelser, kunne Kina støtte konceptet - forudsat det aldrig kom til at omfatte Kina selv.

\section{EU alene om visionen}

Dermed stod EU alene blandt de store tilbage med visionen om en ny aftale efter Kyoto-modellen, en position, der ikke blev lettere af, at en 
række af de store tidligere Kyotolande som Japan, Canada og Rusland gjorde det klart, at de ikke ville være med til en ny omgang forpligtelser, der ikke omfattede vækstøkonomierne. Medvirkende til den voksende modstand over for en ny Kyoto-konstruktion var også erkendelsen af, at alene stigningen i Kinas udledninger langt ville opveje selv meget dybe reduktioner i de gamle Kyoto-lande.

For især europæiske miljøbevægelser blev spørgsmålet om en aftales form afgørende. Hvis der ikke i tiden inden udløbet af Kyotos første forpligtelsesperiode 2008-12 kunne opnås enighed om en ny, blev det $\mathrm{i}$ vide kredse oplevet som et ubærligt tilbageskridt. Da aktive miljøorganisationer står stærkest i Europa, kom de europæiske klimaministre under mærkbart pres for at gøre bevarelsen og videreførelsen af Kyoto til et omdrejningspunkt for EU's politik. Kravet fik stærk støtte også fra udviklingslandene, som så helt nye perspektiver i tanken om, at også den finansielle støtte til såvel udledningsbegrænsning som klimatilpasning ville blive en juridisk forpligtelse for industrilandene.

Dilemmaet var, at der er en indbygget trade-off mellem en stærk formel forpligtelse og et højt ambitionsniveau, både når det gælder reduktioner og finansiel støtte. Der skulle med andre ord træffes et politisk valg mellem at gå efter en stærk aftale med et lavt ambitionsniveau.
Eller efter en svag med et højt. De fleste europæiske ministre veg tilbage fra dette valg og forlangte i stedet begge dele, vel vidende at ingen af verdens to største udledere, USA og Kina, ville kunne acceptere nogen af dem. Europa blev generelt bakket op af miljøbevægelserne, som til gengæld fik svært ved at gå i rette med EU, der i kraft af basisår og beregningsmetode var i stand til at fremstille sine egne reduktionsmålsætninger som mere ambitiøse, end de faktisk var i forhold til andre store industrilande.

Usikkerheden om de virkelige ambitionsniveauer blev yderligere forstærket af muligheden for gennem $\mathrm{k} ø \mathrm{~b}$ af kreditter at gennemføre nationale og regionale reduktioner i andre lande. Mens ordningen kan give god mening ud fra ønsket om at overføre grøn teknologi til særlig vækstøkonomierne, udgør kreditterne samtidig faren for at udhule aftalen, sådan som det også er tilfældet under Kyoto. Når industrilande, der er underlagt konkrete reduktionsforpligtelser, kan købe kreditter i udviklingslande, der ikke har forpligtet sig til nogen begrænsning, bliver den indbyrdes byrdefordeling helt uigennemskuelig.

EU har ganske vist aftalt med sig selv, at kun op til halvdelen af Unionens forpligtelser kan købes fri via kreditter, men en række andre industrilande har ikke underlagt sig selv tilsvarende begrænsninger. For eksempel forbeholder USA sig ret til 
selv og uden begrænsning at afgøre, hvorledes kreditterne skal beregnes og godskrives. Det vel at mærke uden det står klart, hvordan det undgås, at de købte kreditter både regnes med ved opfyldelsen af reduktionsforpligtelsen og ved opg $\varnothing$ relsen af salgslandets udledningsreduktion.

I forhandlingsprocessen satte disse fundamentale stridspunkter og uklarheder sig i to forskellige opfattelser af forhandlingernes mål. For langt de fleste udviklingslande måtte rækkefølgen være, at ilandene først forpligtede sig på et nyt sæt reduktioner under Kyoto, og at ulandene på det grundlag tilkendegav, hvilke tiltag de på frivillig basis ville påtage sig, forudsat ilandene stillede den nødvendige finansiering til rådighed for såvel reduktioner som klimatilpasning. For de fleste ilande var målet en ny, global og forpligtende aftale, der stadig skelnede mellem forskellige kategorier af lande, men som gjorde det klart, at alle måtte yde deres, og at ansvaret voksede i takt med den økonomiske vækst og betydning.

Da det viste sig umuligt at bygge bro over denne kløft, blev det under COP13 på Bali i december 2007 besluttet at give mandat til parallelle forhandlinger om begge dele, uden at det blev klart, hvordan de to forhandlingsspor kunne eller skulle spille sammen. Betænkelighederne ved at indlede forhandlingsprocessen med et uklart og selvmodsigen- de mandat blev fejet til side, og USA valgte efter en første afvisning at godtage mandatet, da de toneangivende udviklingslande i deres stemmeforklaring havde gjort det klart, at de ikke opfattede det tvedelte mandat som et carte blanche til at undgå fremtidige forpligtelser. Mere kyniske iagttagere hæftede sig også ved, at Bali-mandatet blev tiltrådt af præsident Bush' team på et tidspunkt, hvor det stod klart, at det med stor sikkerhed ville blive en nyvalgt demokratisk præsident, der kom til stå over for den umulige opgave at levere amerikansk tilslutning til en ny global klimaaftale samme år som vedkommende overtog sit embede.

Det viste sig efterfølgende umuligt at gøre fremskridt i FN-forhandlingerne, hvor der ganske vist på teknisk niveau kunne skabes fælles forståelse på en række felter, men hvor egentlige fremskridt i det ene spor blev taget som gidsel for tilsvarende i det andet. Resultatet blev, at FN-forhandlingerne trods endeløse møder stod i stampe.

\section{Hopenhagen}

I et forsøg på at vriste sig fri af det dødvande, der havde ramt FN-forhandlingerne, besluttede præsident Obama kort efter sin tiltræden i januar 2009 at genoplive det forum for dialog mellem de største økonomier, som allerede hans forgænger havde iværksat. Forskellen var, at 
mens tilliden til Bush var i bund også når det gjaldt klima - kunne forventningerne til Obama og hans team dårligt være under himlen. Derfor skabte initiativet fornyet håb om, at der gennem uformelle drøftelser på højt niveau mellem de omkring 20 største og mest energiforbrugende $ø$ konomier i verden kunne skabes en forståelse, der kunne bryde stilstanden i FN-forhandlingerne og bane vejen for en aftale i København.

Major Economies Forum on Energy and Climate blev fra begyndelsen omgæret af intens politisk interesse både af de lande, der var inviteret med, og af dem, der ikke var. Det var ingen hemmelighed, at der i den nye amerikanske administration trivedes ambitioner om at skabe et nyt, mere institutionaliseret forum, der kunne håndtere globale spørgsmål mere effektivt end $\mathrm{FN}$, der havde vist sig svagt i forhold til det 21 . århundredes problemer med international økonomi, ressourcer, klimaforandringer og bæredygtig udvikling. Med langt størstedelen af verdens $\varnothing$ konomien rundt om et forholdsvist lille bord så flere de første spæde ansatser til noget, der en dag kunne udvikle sig til et centralt globalt organ.

For Obamas folk blev det af afgørende betydning at demonstrere, at disse møder ikke udgjorde et alternativ til FN - endsige et forhandlingsforum. Det var åbenbart, at den selvbestaltede gruppe savnede FN's og universalismens legitimitet, og at en lang række interesser ikke sad med ved bordet - de fattigste eller de mest udsatte lande, for at tage et par eksempler. Omvendt var navnlig disse lande stærkt interesserede i, at der blev skabt fremdrift i forhandlingerne.

\section{Ulmende konflikt}

Den europæiske repræsentation til møderne kom til at udgøre et særligt problem for amerikanerne. Obama havde inviteret personlige repræsentanter for de store landes stats- og regeringschefer, og han lagde ikke skjul på, at bagtanken var forud for klimamødet i København at samle sine kolleger for at forsøge at fremtvinge et forhandlingsgennembrud på øverste politiske niveau. Den konstruktion pustede i snart sagt alle lande til en ulmende konflikt mellem forskellige interessenter i klimaspørgsmålet, der er forankret vidt forskelligt i de respektive landes regeringsapparater.

Mens kompetencen i USA ligger hos en af præsidenten særlig udpeget klimaforhandler i udenrigsministeriet, ligger den i Kina hos den magtfulde Nationale Kommission for Udvikling og Reformer. I de fleste udviklingslande er klimaforhandlingerne et traditionelt FN-spørgsmål, der håndteres af diplomater fra udenrigsministerierne - i vækstøkonomierne dog i stigende omfang i tæt infight med de respektive landes 
miljøministre, mens spørgsmålet i Europa typisk er forankret i særlige klimaministerier - ofte med ambitiøse yngre ministre i spidsen. Mens disse vidt forskellige repræsentanter udgjorde forhandlerne ved FN-møderne, opstod nu - især, men bestemt ikke kun, i de europæiske lande - spørgsmålet om, hvem de respektive stats- og regeringschefer ønskede som deres personlige repræsentanter?

Valget stod generelt mellem den ansvarlige klimaminister eller i det flertal af lande, der var medlem af G20, den såkaldte sherpa, som direkte under statslederen er ansvarlig for forberedelsen af G20 topmøder. Spørgsmålet var langt fra trivielt, og selv om det hurtigt kom til at dreje sig også om personlige ambitioner og politiske magtkampe i de enkelte regeringer, hang svaret sammen med en grundlæggende konflikt om, hvad der var målet for mødet i København.

Stærkt forenklet lå regeringscheferne på den linje, at der måtte findes en politisk landingsbane, der på et overordnet niveau formulerede en række mål og midler, der væsentligt kunne styrke kampen mod klimaændringer og danne grundlag for et stærkere internationalt samarbejde på området. Deres sherpaer, som typisk er højtstående diplomater eller nære medarbejder med direkte reference og daglig kontakt til regeringschefen, kunne håndtere sådanne spørgsmål. De har lang er- faring med komplicerede forhandlinger i politisk minefyldt farvand. Til gengæld havde de typisk begrænset indsigt i den mere substantielle del af klimadossieret - endsige dybere forståelse for de komplicerede stillingskrige i FN-forhandlingerne, der i sidste ende skulle danne ramme om et resultat i København.

Obama satte sin egen sherpa fra Det Hvide Hus i spidsen for gruppen og signalerede dermed, at det var den vej, han ville.

De europæiske klimaministre var lige som deres bagland blandt europæiske miljøorganisationer opmærksomme på, at denne vej førte væk fra Kyoto-sporet og dermed fra den aftale, der var selve kernen af deres respektive ressort. Trækket i retning af stats- og regeringscheferne var dermed en bevægelse, der i stedet for at give de respektive klimaministre mere kompetence i takt med, at klimasagens mange aspekter kravlede op ad den storpolitiske dagsorden, risikerede at reducere dem til overforhandlere i endeløse FN-forhandlinger, hvor deres modparter ofte ville være diplomater fra udviklingslandene.

Denne udsigt var så meget desto mindre attraktiv, som det var helt klart, at selv et mirakuløst gennembrud i Obamas forsøg på at haste en relativt ambitiøs klimalovgivning gennem kongressen på ingen måde ville nærme USA til en ny global aftale efter Kyoto-modellen. Uden udsigt til at USA selv i heldigste fald vil- 
le tiltræde juridisk forpligtende reduktionsmål, var det utænkeligt, at Kina eller de andre vækst $ø$ konomier ville gøre det, hvilket reducerede en europæisk forlængelse af Kyoto til en rent symbolsk handling.

Bag den forbitrede kamp i de enkelte lande om kontrollen med Major Economies lå således vidt forskellige opfattelser af, hvad der kunne og skulle nås i København. I Europa vandt de fleste klimaministre denne kamp, dog således at de respektive regeringschefers sherpaer også deltog i møderne. På den måde blev skismaet mellem den politiske og den juridisk bindende aftale båret med ind også i dette uformelle forum.

Selv om ingen havde svaret på, hvorledes den gordiske knude af grundlæggende uforenelige positioner mellem USA, Kina og EU skulle løses, var det ekstremt følsomt politisk at lægge ambitionen om en altomfattende, ambitiøs og juridisk bindende aftale i graven. Men COP 15 nærmede sig hastigt, og FN-forhandlingerne var låst i netop det uløselige problem mellem de store aktører.

\section{Den danske strategi}

Danmark, der som kommende vært for klimamødet spillede en særlig rolle, forfulgte en tresporet strategi. Dels engagerede Danmark sig intenst i FN-forhandlingerne, hvor man på alle niveauer pressede på for at opnå konkrete fremskridt og teknisk forberede en aftale, hvis det lykkedes at opnå et storpolitisk gennembrud. Dels deltog Danmark som observatør i Major Economies møderne. Og endelig var danske organisationer fra alle dele af samfundslivet initiativtagere til og værter for forberedende møder, der var med til både at forankre forberedelsesprocessen bredere og dybere, end noget tidligere FN møde, og som samtidig bidrog til at opbygge det politiske momentum for en aftale $\mathrm{i}$ København.

Den danske strategi var forankret i regeringens klimakonferenceudvalg under statsministerens ledelse, hvor løbende justeringer og danske initiativer og udspil blev drøftet og vedtaget. Selv om også det danske regeringsmaskineri udlevede sin egen version af de europæiske tovtrækkerier om, hvem der lagde linjen og tegnede regeringen, forblev denne struktur uændret hen over statsministerskiftet i april 2009, men det var en utaknemmelig opgave for den nye statsminister at skulle overtage denne uhyre komplicerede internationale opgave på et tidspunkt, hvor den gik ind i en afgørende fase.

Sidst på foråret traf Obama beslutning om at sætte alt ind på at opnå et politisk forhandlingsgennembrud ved et Major Economies topmøde, der skulle afholdes i forbindelse med G20 topmødet i l'Aquila i juli 2009. Det blev ikke blot første gang, en dansk statsminister deltog i et så- 
dant møde blandt verdens største, men også den nye statsministers første møde med de fleste af sine kolleger. Gennem et intensivt forhandlingsforløb op til topmødet gik de store lande ind i realitetsdrøftelser af, hvor langt de hver især kunne gå, og topmødeerklæringen afspejlede reelt det muliges grænse.

I optakten til København var der i flere af de vigtigste lande vedtaget nationale energi- og klimaplaner, der nu dannede udgangspunkt for de enkelte landes udspil i forhandlingerne. Der var i alle tilfælde tale om uhyre tungt lovgivningsarbejde med vidtrækkende betydning for de nationale økonomier, og det stod i forhandlingerne klart, at de store aktører hverken kunne eller ville afvige fra disse vedtagelser. Der kunne files på detaljerne, men ikke ændres på det grundlæggende. Hvis noget skulle vedtages i København, måtte det $\mathrm{i}$ alt væsentligt bygge på de elementer, der var indkredset i l'Aquila.

Det var realiteten, men det var langt fra opfattelsen i en opinion, der forventede en egentlig aftale med forpligtende reduktionsmål for i det mindste industrilandene - et mål der lå helt uden for rækkevidde efter l'Aquila.

FN's forberedelse blev også kompliceret af kompetencekonflikter mellem generalsekretæren og klimasekretariatet i Bonn. Alligevel gik såvel generalsekretæren som chefen for konventionssekretariatet i efteråret ud med klare advarsler om ikke at skrue forventningerne for højt op. Begge sagde i klar tekst, at en juridisk bindende aftale i København lå uden for det muliges grænser. Et budskab, der ikke var populært, og som i det store og hele blev ignoreret af en stadig mere entusiastisk verdensopinion. Alle efterlyste globale forpligtelser. Men kun få lande var rede til at blive en del af dem.

I september inviterede FN's generalsekretær en større gruppe statsog regeringschefer til uformelle konsultationer i New York i forbindelse med åbningen af årets generalforsamling. Her nikkede en bredt sammensat gruppe til generalsekretærens forslag om at give den danske statsminister mandat til uformelt at sondere mulighederne. Det var første gang, at nogen uden for de formelle FN-forhandlinger fik et sådant mandat, og selv om det var holdt i meget generelle vendinger, forlod stats- og regeringscheferne hinanden med den forståelse, at de ville mødes igen i København og der lande en aftale, der repræsenterede et virkeligt og væsentligt politisk skridt fremad.

Konturerne af et af verdens mest omfattende topmøder begyndte at tegne sig. Det gjorde konturerne af en aftale derimod ikke.

\section{Håb, kaos, sammenbrud}

Hen over efteråret 2009 gennemførte det danske formandskab en lang række konsultationer på alle niveau- 
er og i en bred vifte af fora. Sigtet var skridt for skridt at opbygge et nuanceret og velfunderet billede af, hvad der realistisk kunne opnås enighed om i København. Selv om det ikke kunne få karakter af en juridisk bindende aftale, var det afgørende for formandskabet, at ambitionsniveauet om at begrænse de menneskeskabte temperaturstigninger til to grader blev knæsat, og at der inden for de konkrete substansområder blev vedtagelser, der repræsenterede konkrete skridt fremad mod faktiske reduktioner. Hele mandatet fra Bali måtte udfyldes, og en balance mellem de enkelte punkter findes.

Formandskabets bestræbelser blev afspejlet i en tekst, der løbende blev revideret og godkendt i regeringens klimakonferenceudvalg, og som dannede udgangspunkt for konsultationerne i forskellige sammenhænge med de enkelte lande.

Et grundlæggende problem var, at mens der syntes at anes antydningen af en begyndende konvergens omkring de politiske tekstforslag, formandskabet arbejdede med, voksede forventningerne til en altomfattende aftale videre i offentligheden, hvor ingen havde lyst til at påtage sig det politiske ansvar for at punktere ballonen. Blandt mange herskede opfattelsen af, at hvis tilstrækkeligt mange ønskede en stærk, bindende aftale tilstrækkeligt stærkt, ville stats- og regeringscheferne ikke kunne undlade at vedtage den.
Der blev talt mere og mere om at 'lægge pres' på især USA, hvor klimalovgivningen syntes uhjælpeligt strandet i en kongres, der ikke forekom udpræget følsom over for det pres. I oktober benyttede statsministeren et internationalt parlamentarikermøde til for første gang offentligt at beskrive hovedlinjerne i de tekstforslag, formandskabet forsøgte at skabe opbakning til. En grundtanke var at udskyde de uløselige spørgsmål omkring en fremtidig aftales formelle karakter og i stedet søge politisk enighed om hovedlinjer og konkrete skridt forankret i nationale handlingsplaner.

I ugerne op til topmødet i december intensiveredes de uformelle konsultationer, og weekenden inden FN-mødet tog sin formelle begyndelse, samledes topforhandlerne fra en bred vifte af lande i Eigtveds Pakhus i København, hvor de for første gang i samlet flok gennemgik de danske tekstudkast.

Mødet forløb over forventning, fordi formandskabets tekster overlevede dette første møde med en repræsentativt sammensat gruppe forhandlere. Nok var der fra flere sider drøje hug og alvorlige betænkeligheder ved flere af formandskabets greb og kompromisforslag, men det var dog langt bedre end blank afvisning. Formandskabet fik igen mandat, nu til at revidere teksterne i lyset af de fremsatte bemærkninger. Det uformelle møde blev afsluttet med en middag, hvor en stor del af 
konferencens nøglespillere i næsten højstemt forventningsfuldhed så frem til de kommende ugers forhandlinger. Ingen tvivl om, at det ville blive svært og hårdt. Men et fornuftigt resultat syntes for første gang at tegne sig i horisonten.

Allerede på konferencens anden dag vendte stemningen. En tidligere version af et af de danske udkast blev lækket - og spundet som et hemmeligt forræderi planlagt af formandskabet for at kuppe FN-forhandlingerne, som modsat det politiske spor stadig var uhjælpeligt fastlåste.

Godt hjulpet af pressen, miljøorganisationer og de mindst konstruktive kræfter blandt de forhandlende lande blev en stemning af kupforsøg og mistillid pisket op. Vildtvoksende konspirationsteorier fik frit løb i den højspændte atmosfære, og formandskabet, der også var svækket af indbyrdes kævl om ansvaret for lækagen og dens skadevirkning, var ude af stand til at mobilisere et svar, der kunne dæmme op for den negative dynamik.

Formandskabet var ganske enkelt ikke forberedt på at se selv samme delegerede, som få dage tidligere havde skålet på et succesfuldt møde, nu for rullende kameraer mistænkeliggøre dets motiver. (Klimachefen hos Mandag Morgen, Per Meilstrup, gengiver i sin bog fra 2010 Kampen om klimaet. Historien om et topmøde der l $\phi b$ løbsk et udvalg af sådanne konspirationsteorier blandt FN-forhandler- ne. Selv om fremstillingen på væsentlige strækninger er uvederhæftig, giver den et veloplagt indtryk af det dramatiske topmøde og nogle af de frustrationer, der bredte sig også i dele af den danske lejr.)

\section{Redningsforsøg}

De følgende dage blev præget af formandskabets forgæeves fors $ø g$ på at komme tilbage i offensiven. De reviderede tekster fra weekendens møde var klar, men de kræfter, der allerede så effektivt havde stukket en kæp i hjulet, fortsatte en målrettet bestræbelse for på forhånd at kriminalisere ethvert forsøg fra formandskabet på at fremlægge kompromistekster.

En ulykkelig alliance opstod mellem maksimalister blandt miljøforkæmpere, der ønskede en stærk aftale, og de mest destruktive medlemslande, der under dække af maksimalistiske positioner arbejdede for det modsatte. Ved at insistere på resultater, der på forhånd var udelukket, skabtes en stemning, der på samme tid blokerede ethvert fremskridt i de formelle forhandlingsgrupper og stillede sig i vejen for et politisk initiativ. Som dagene gik, blev stemningen stadig mere anspændt i takt med, at alle ventede, at andre ville bukke under for det pres, der fulgte med de øverste politiske lederes snarlige ankomst.

For det allerede hårdt pressede formandskab blev det en ekstra be- 
lastning, at en række fremtrædende stats- og regeringschefer i lyset af det truende sammenbrud valgte at fremskynde deres ankomst til København, hvor de første indfandt sig allerede tidligt i anden uge. Det er højst usædvanligt, at det øverste politiske niveau deltager i egentlige mellemstatslige forhandlinger af denne karakter, og der var ikke truffet forberedelse til en forhandlingsproces på det niveau. Dette så meget desto mindre som de tilstedeværende toppolitikere ikke repræsenterede et bredt udsnit, men overvejende var vestlige ledere med en stærk politisk interesse i et resultat.

Sideløbende fortsatte løbende konsultationer med hovedparten af de lande, der havde deltaget i de forudgående uformelle drøftelser. Fra alle sider udtryktes ønske om at få situationen under kontrol, og der blev i de små forhandlingsrum arbejdet intenst med de politiske tekster. Spændingerne og nervøsiteten internt i de enkelte delegationer blev et voksende problem. De udmattede FN-forhandlere, der løb panden mod muren i de formelle forhandlingsgrupper, så med mistænksomhed på deres kolleger, der - typisk med direkte referat til de tilrejsende ledere - konsulterede uformelt om politiske tekster, der slet ikke indgik i de formelle forhandlinger. Omvendt voksede presset på de politiske rådgivere for at præsentere en landingsbane for topmødet, der skulle tage sin begyndelse med dron- ningens middag på Christiansborg torsdag aften.

Samme eftermiddag fik formandskabet omsider mere formel tilslutning til at indkalde en uformel gruppe for at drøfte 'en ramme' for mødets resultat. Intense konsultationer afslørede, at der maksimalt på dette meget fremskredne tidspunkt kunne blive tale om en kort tekst indeholdende en politisk afbalanceret syntese af de længere papirer, formandskabet ikke havde fået lov til at fremlægge i de formelle forhandlingsgrupper. (Daværende afdelingschef i finansministeriet, Per Callesen, der deltog i de afgørende forhandlinger, har i Nationaløkonomisk Tidsskrift 148 (2010) i en kommentar til Per Meilstrups førnævnte bog givet en glimrende fremstilling af formandskabets dilemma omkring de forskellige tekster.)

For formandskabet var vanskeligheden, at der selv dagen før topmødet, der tegnede til at blive et af de mest omfattende nogen sinde, ikke var kommet en eneste linje forhandlet tekst ud af de formelle FN-forhandlinger. Forventningerne til, hvad resultatet fra København skulle indeholde, var stadig helt forskellige fra EU over USA til Kina og de andre store vækstøkonomier, og imellem dem stod en række stærke aktører, der ihærdigt forfulgte egne dagsordner, samt dybt frustrerede fattige og sårbare lande, der frygtede, at det hele skulle gå op i røg.

Stemningen blev yderligere pisket 
op af den politiske hype omkring topmødet, og der blev fra alle sider udøvet massivt pres på formandskabet for at tage initiativet og skære igennem - dog med vidt forskellige forestillinger om, hvor snittet skulle lægges, og hvad et resultat skulle indeholde.

Under dronningens middag torsdag aften indkaldte formandskabet $i$ nært samråd med FN's generalsekretær en repræsentativ forhandlingsgruppe sammensat efter FN's sædvanlige principper.

Da gruppen mødtes over midnat, præsenterede formandskabet en kort tekst, der efter en drøftelse blandt de tilstedeværende stats- og regeringschefer blev godkendt som arbejdsgrundlag for et slutdokument. Tilslutningen til dette forhandlingsoplæg udgjorde et vendepunkt i de internationale klimaforhandlinger, fordi det for første gang lykkedes at konstruere en tekst, som uden at være forpligtende dog rummede såvel de tiltag, industrialiserede lande ville forpligte sig til, som de tiltag, en række udviklingslande ville gennemføre som et led i aftalen.

Dermed var den gordiske knude, der gjorde det umuligt at forhandle i- og ulandes tiltag i sammenhæng, hugget over. Prisen var, at dokumentet var kort, generelt og uden konkrete forpligtelser. For EU, mange mindre ulande og betydelige dele af opinionen var det en stor skuffelse; for de største udledere stadig mere, end de kunne tiltræde. Teksten blev forhandlet af stats- og regeringschefernes personlige repræsentanter natten til fredag morgen, hvor statsog regeringscheferne igen mødte op i forhandlingsgruppen. Nattens forhandlinger havde ikke bragt konsensus nærmere, og efter yderligere et par timers frugtesløse drøftelser på højeste niveau svandt håbet om, at der kunne opnås enighed om de konkrete formuleringer i udkastet til Copenhagen Accord.

Tiden var ved at rinde ud, og det formelle topmøde skulle indledes med taler og ceremoniel. USA havde i slutfasen været repræsenteret af udenrigsminister Hillary Clinton, der annoncerede en væsentlig amerikansk indrømmelse vedrørende de finansielle spørgsmål. Ud på formiddagen ankom så præsident Obama, der tilførte forhandlingerne i det lille rum fornyet liv, og som med en aktiv indsats forsøgte at bløde fastlåste positioner op. Pludselig var der fremdrift, og formanden besluttede at fortsætte bestræbelserne for at nå i mål sideløbende med afviklingen af det formelle topmøde. Det var ikke nogen let eller populær beslutning - men omvendt den eneste, der kunne holde håbet om et resultat $i$ live.

I løbet af dagen blev der forhandlet i den samlede gruppe og på kryds og tværs mellem stats- og regeringscheferne og delegationerne. Næppe i nogen anden sammenhæng siden anden verdenskrig har 
en så bredt sammensat og så betydende forsamling af verdens ledere forhandlet direkte med hinanden, ansigt til ansigt, om verdens tilstand og den fremtidige fordeling af vækst og velstand. Den storpolitiske nerve var blottet, og ingen kom fra det lille rum uden at mærke smerten.

\section{Global magtforskydning}

Af historisk rækkevidde var et afgørende møde, der fandt sted sidst på eftermiddagen i kanten af drøftelserne i forhandlingsgruppen.

USA og Kina havde hele eftermiddagen hver for sig søgt at sikre sig støtten fra de øvrige store vækst $ø$ konomier, Indien, Sydafrika og Brasilien, men de tre landes ledere havde undgået direkte kontakt med begge sider. Da præsident Obama sidst på eftermiddagen blev klar over, at det omsider var lykkedes premierminister Wen at samle sine kolleger til en konsultation i et lokale på den anden side af den store konferencehal, gik præsidenten spontant derover.

Uden forudgående invitation masede han ind til i mødet, hvor den kinesiske chefforhandler, der sad bag sin premierminister, mødte ham med replikken: "Hr. Præsident, dette er et lukket møde, her kan De ikke komme". Da det blev oversat, intervenerede Brasiliens præsident Lula, der sad over for Wen, og ved hvis side udenrigsminister Celso Amorin sad, med bemærkningen henvendt til sin udenrigsminister:
"Hør Celso, skal vi ikke gøre Barack til medlem af den brasilianske delegation, så kan han måske låne din plads?"

Episoden afspejler den globale magtforskydning, der blev tydelig under COP15. Hverken USA eller EU kan sætte dagsordenen endsige fastholde de store udviklingslande i forhandlinger på egne præmisser. Omvendt kan Kina, men kun i den udstrækning Kina er i stand til at mobilisere også de øvrige store vækstøkonomier i en fælles front. Interessemodsætningerne mellem de store vækstlande er imidlertid også til at få øje på, og for Brasilien, Indien og Sydafrika er det ikke indlysende at danne blok med Kina og front mod USA. Spillet er åbent og det blev for første gang udfoldet $\mathrm{i}$ den efterfølgende direkte forhandling mellem den amerikanske præsident og hans kinesiske modpart, kritisk overvåget og kommenteret af statslederne fra de tre øvrige lande samt deres ministre.

I mødet blev to spørgsmål afgørende: Spørgsmålet om hvordan klimatiltag fra hhv. industri- og udviklingslande skulle registreres i dokumentet. Og spørgsmålet om, hvordan gennemførelsen af dem skulle opgøres, verificeres og rapporteres. Der blev fundet kompromissprog vedrørende rapportering og revision. Men i virkeligheden var det største og mest kontroversielle gennembrud selve tekstens karakter, hvor den korte politiske tekst på tre 
sider henviste til to bilag, som indeholdt de tiltag, hhv. industrilande og udviklingslande ville gennemføre.

Det betød, at såvel USA som de store udviklingslande her for første gang accepterede princippet om, at deres tiltag også vil blive en del af en international aftale.

\section{Vigtigste resultat}

Denne indrømmelse blev COP15's vigtigste resultat, som betyder, at de tilsagn, som blev givet op til København efterfølgende er indskrevet i en registratur, der løbende opdateres af FN. Selv om de afgivne tilsagn langt fra er tilstrækkelige, er der hermed for første gang etableret en metode for at fastholde, måle og vurdere de enkelte landes bidrag og dermed også deres samlede effekt.

Dette gennembrud var kun muligt, fordi både premierminister Wen og præsident Obama sammen med de øvrige BASIC-landes ledere gik ud over de røde linjer, de på forhånd havde defineret, og fordi premierminister Wen valgte at tilsidesætte sin klimaforhandlers indtrængende råd om ikke at give en sådan indrømmelse. (Der deltog ingen fra formandskabet eller FN i mødet mellem Obama og BASIC-lederne. Fremstillingen her bygger på efterfølgende afrapporteringer fra de deltagende. De amerikanske politologer fra Brookings Institute, William Antholis og Strobe Talbott sam- menfatter i deres bog Fast Forward: Ethics and Politics in the Age of Global Warming (2010) indtryk fra en række deltagere.)

Efter mødet briefede præsident Obama de ventende ledere fra EU om resultatet. De kendte naturligvis hovedteksten, men kunne nu konstatere, at Obama dels personligt havde forhandlet de sidste knaster på plads, dels havde solgt en af EU's sidste mærkesager, nemlig ønsket om ikke blot at fastslå to graders målsætningen, men også den videnskabelige vurdering, at forudsætningen for at nå den vil være, at verdens udledninger halveres inden 2050.

$\mathrm{Nu}$ rådede den amerikanske præsident indtrængende sine europæiske kolleger til at acceptere teksten, som den forelå. Der var reelt ikke andet, de kunne gøre, og først på aftenen forsamledes forhandlingsgruppens ledere igen til et afsluttende møde. Her viste der sig at være yderligere et par mere tekniske udeståender, som skulle afklares, og mens formandskabet og FN-sekretariatet kæmpede for at få lukket The Copenhagen Accord, gik tiden.

Tidligt på aftenen erklærede Obama, at han uopholdeligt måtte af sted for at undgå en snestorm, der truede med at forhindre hans tilbageflyvning til Washington samme nat og deltagelsen i en drøftelse i kongressen af sundhedsreformen næste dag. Han forlod som den første af 'de store' mødet, endnu inden 
teksten var endeligt godkendt i gruppen, hvor frustration blandede sig med vrede, da nyhedstelegrammer kort efter begyndte at tikke ind med Obamas meddelelse til pressen om, at der var indgået en aftale på COP15.

Timingen kunne ikke være mere uheldig for de politiske ledere, der skulle ud og forklare deres mildest talt kritiske offentligheder om aftalen, og forløbet var med til yderligere at forsinke tekstens endelige godkendelse og renskrivning.

De udmattede og skuffede regeringsledere holdt hver deres pressebriefing $\mathrm{og}$ tog så direkte hjem, fulgt af det store antal ledere, der havde deltaget i det formelle topmøde, men ikke i den mindre gruppes forhandlinger, og hvis frustration var både følelig og forståelig. Da teksten og formandskabet endelig var klar til at gå i plenum, var det langt over midnat, og tilbage i salen var stort set kun FN-forhandlerne, der havde været koblet helt af den politiske proces i det forløbne døgn.

Da en synligt udmattet dansk statsminister gik på podiet for at forelægge den tekst, stats- og regeringscheferne var blevet enige om i gruppen, fik vreden, skuffelserne og frustrationerne frit løb hos mange af de delegerede. En del var også allerede denne sene nattetime i gang med at forsøge at rulle de indrømmelser tilbage, som var indeholdt $\mathrm{i}$ Copenhagen Accord. Det uskønne forløb i plenarforsamlingen den nat, da en håndfuld latinamerikanske delegerede modsatte sig en vedtagelse, er velkendt. Da røgen lagde sig lørdag morgen, havde COP15 taget Copenhagen Accord til efterretning, men ikke formelt vedtaget teksten.

Skuffelsen var nu lige så dyb, som forventningerne før mødet havde været høje. I det blamegame, der fulgte, stod formandskabet og navnlig statsministeren og hans rådgivere godt for hug, men også USA og Kina fik deres del af kritikken.

\section{Efter stormen}

Kampen om Copenhagen Accord var først lige begyndt, og hen over nytåret kæmpede FN's generalsekretær og det danske formandskab indædt for at holde liv i de konturer af et globalt kompromis, som teksten og de to bilag trods alt indeholdt. Den uhellige alliance af grønne og sorte maksimalister angreb hårdest, og den håndfuld mellem- og latinamerikanske - olie- og gaseksporterende - lande, der havde modsat sig vedtagelsen, kæmpede videre i New York for at undgå, at teksten slog rod. Paradokssalt var det ikke Copenhagens Accords åbenlyse svaghed, der lå bag modstanden, men tekstens mindre indlysende styrke ved at have skitseret vejen frem i ét forhandlingsspor.

Mens USA og Kina stod ved deres del af kompromiset, var der i flere måneder tvivl, om de øvrige vækstøkonomier ville stå bag den kon- 
struktion, deres politiske ledere havde tilsluttet sig. Først ud på foråret stod det klart, at de lande, der havde deltaget i forhandlingerne, stod ved resultatet - og hvad mere er, langt de fleste efterlevede bestemmelsen om, at de hver især skulle melde deres nationale klimatiltag ind i de to bilag til den politiske tekst. I takt med at det skete, fik Copenhagen Accord den politiske tyngde, der gjorde det muligt for Mexicos følgende formandskab forsigtigt at manøvrere kompromiset fra København ind i en ramme, der muliggjorde konsensus om samme i Cancún året efter - stadig uden bevægelse i de fastlåste positioner i de formelle FN-forhandlinger.

Den politiske ramme, der dermed blev knæsat, kunne så i 2011 i Durban danne afsæt for endnu et forhandlingsmandat, der sigter mod vedtagelsen i 2015 af en juridisk bindende aftale, der skal træde i kraft i 2020, uden det dog står klart, hvilke lande der i givet fald vil være bundet af eventuelle fremtidige reduktionsforpligtelser. Samtidig gik EU og enkelte andre lande symbolsk med til at forlænge Kyoto-protokollen i fem år.

Den optimistiske tolkning er, at de to spor i de formelle FN-forhandlinger dermed omsider begynder at nærme sig hinanden. En mere pessimistisk vil være, at det igen vil vise sig uoverkommeligt at skabe konsensus om en bro, der forbinder industrilandene, vækstøkonomierne og de fattige udviklingslande.

Erfaringerne fra 20 års forhandlinger under Klimakonventionen nærer ikke håbet $\mathrm{om}$, at $\mathrm{FN}$ indenfor en forudsigelige fremtid vil kunne vedtage aftaler, der forpligter medlemslandende i spørgsmål, der ikke kun er af vital betydning for klodens fremtid, men også for de enkelte landes økonomiske og sociale udvikling.

For dem, der bekymrer sig om truende klimaforandringer, er tiden inde til at tænke over hvilke initiativer, der kan samle de kræfter, der $\varnothing n s k e r$ at medvirke til en løsning uden at give dem, der har andre interesser, mulighed for at blokere for et praktisk samarbejde om konkrete tiltag.

Bo Lidegaard er historiker, dr.phil. Han deltog $i$ begyndelsen af 1990'erne i forhandlingerne om FN's klimakonvention og har siden varet dansk forhandler ved flere FN-topmøder. 2005-11 var han departementsråd $i$ Statsministeriet, fra 2007 som leder af klimasekretariatet. Siden april 2011 chefredaktør for Politiken. 